relationship was observed between androstenone and parameters closely related to the proportion of muscle in the carcass.

\title{
Total or partial dissection of pig carcasses. Signification of EEC references
}

\author{
B. DESMOULIN, R. CHALIER, P. POMMERE'T \\ I.N.R.A., Station de Recherches sur l'Élevage des Porcs \\ $7835^{\circ}$ Jouy-en-Josas (France) \\ I.T.P., Centre Expérimental de Pen Arlan Maxent \\ 35380 Plélan-le-Grand (France)
}

A total of 445 pig carcasses with a net weight of 70 to $90 \mathrm{~kg}$ and a mean composition of $x=48.2$ p. 100 muscles $(s x=6.03)$ were dissected according to the EEC method. The estimations based on the composition of cuts were made according to the pieces used (partial dissection) and to the accuracy of the dissection procedure (simplified dissection) $\mathrm{X}^{1}$ being the percentage of muscles only, $\mathrm{X}^{2}$ the percentage of muscles plus intermuscular fat, $\mathrm{X}^{3}$ that of meat without external fat but with bones.

The main results were the following:

1) After complete dissection of ham and loin + backfat the EEC reference relative to the percentage of muscle of the whole carcass was calculated with a residual error of $0.66 \mathrm{p}$. I muscle.

Total weight of muscles for the whole ham + loin with backfat allowed to control $98.7 \mathrm{p}$. I of the variance of the total weight of carcass muscles according to the following equation:

2) The simplified dissection led to the following estimations of the $\mathrm{EEC}$ reference.

The percentage of lean + internal fat $\left(\mathrm{X}_{2}\right)$ in ham and loin with backfat produced a residual error of I.OO p. Ioo muscles. The absence of trimming of internal fats overestimated by $3 . \mathrm{I}$ to $3.3 \mathrm{p}$. Ioo the percentage of muscles in fat pigs (threshold $40 \mathrm{p}$. 100) as compared with lean pigs (only $55 \mathrm{p}$. IOO of the EEC table).

The percentage of meat without external fat but with bones $\left(\mathrm{X}_{3}\right)$ of all cuts produced a residual error of $\mathrm{I} .44$ to $\mathrm{I} .7 \mathrm{I}$ p. Ioo muscles. Deboning of ham reduced considerably the estimation error. Tables indicating the correspondance between the EEC reference and the composition of the main cuts were established. They may contribute to a rapid arbitrage of grading problems. This could result in a more harmonious application of FEF regulation.

\section{Relationship between anatomical composition and ham conformation}

\author{
B. L. DUMONT, O. SCHMITT, T. BOULLEAU, J. LEFEBVRE \\ I.N.R.A., Laboratoive de Recherches sur la viande \\ $7835^{\circ}$ Jouy-en-Josas (France) \\ I.N.R.A., Labovatoire de Génétique Factorielle \\ 78350 Jouy-en-Josas (France)
}

The relationships between anatomical composition of ham (tissue percentages in the cut, percentage of each muscles within ham musculature) and conformation were studied. Conformation was defined by an objective index calculated from measurements taken on the profiles of the outlines of ham images.

Seventy-six pigs of various conformation and live weight ( 90 to $140 \mathrm{~kg}$ ) were considered. 
The results of different statistical analysis (simple and multiple regressions, multivariate analysis according to the method of centred data) show that the improvement of conformation leads to an increase in the muscle to bone ratio and to changes in the muscle distribution (increase in the percentage of $M$. Semimembranosus, decrease in the percentage of thigh muscles). The variation of conformation thus appreciably modify the commercial and technological value of pork carcasses.

\title{
Objective method for measuring ham conformation
}

\author{
B. I. DUMONT, O. SCHMITT, T. BOUL,EAU \\ I.N.R.A., Laboratoive de Recherches sur la Viande \\ 78350 Jouy-en-Josas (lirance)
}

An objective method for measuring ham conformation in pigs is proposed. Carcasses were considered in internal-medial and in dorsal-medial views. Their images were recorded (by photography or by T.V. camera) and reproduced so that the limb length be the same for all animals. Variations in conformation were measured by quantifying the shape variations exhibited in relation to reference axis, by the outlines of the hindlimb. One of the axis goes from the hock tip to the anterior edge of the ischio-pubis symphysis, and the other represents the vertical axis passing through the hock tip.

Application of this method to a sample of pig carcasses of various conformations is described.

\section{Presence and distribution of giant muscle fibres in pig muscles}

\author{
O. SCHMITT, B. L. DUMONT \\ Laboratoire de Recherches sur la Viande \\ I.N.R.A., $7835^{\circ}$ Jouy-en-Josas (France)
}

The presence and distribution of giant muscle fibres (GF) were systematically explored in different muscles from four genetic types of pigs (Large White, French Landrace, Belgian Landrace and Pietrain).

The presence of GF was highly variable; some muscles did not include any and others up to some ten thousand. In some areas of the muscles these $G F$ represented up $5 \circ \mathrm{p}$. Ioo of the total number of the muscle fibres. GF were generally distributed around the muscle border. Within the muscle bundles they were nearly always located against the perimysium.

A map of the distribution of GF in different muscles was made. The presence of GF was marked in the hypertrophied types (Belgian Landrace and Pietrain). Increase in the number of giant muscle fibers is related to the rate of muscle hypertrophy. 